\title{
Perceptions about the hospital environment from the perspective of high-risk puerperal women based on Florence Nightingale's theory
}

\author{
Percepções da puérpera de alto risco acerca do \\ ambiente hospitalar à luz de Florence Nightingale
}

Percepciones sobre el ambiente hospitalario en la perspectiva de la puérpera de alto riesgo a la luz de Florence Nightingale

\section{Ariane Thaise Frello Roque ${ }^{a}$ Telma Elisa Carrarob}

DOl: http://dx.doi.org/10.1590/19831447.2015.04.51057 a University of Alberta, Faculty of Nursing, Edmonton, Alberta, Canada.

- Universidade Federal de Santa Catarina (UFSC), Programa de Pós-Graduação em Enfermagem, Departamento de Enfermagem. Florianópolis, Santa Catarina, Brasil.

\section{ABSTRACT}

Objective: to understand the perceptions of high-risk puerperal women about the hospital environment based on Florence Nightingale's theory. High-risk postpartum period is the period of time when post-partum women care for their babies in the neonatal ICU, and experience high stress levels.

Methods: it is a qualitative study with narrative approach based on Florence Nightingale's theory, conducted at a public institution in southern Brazil, from January to March 2010. Seven mothers over 18 years with newborns admitted to the neonatal ICU were the research subjects.

Results: the contextualization of their narratives, the caring environment in which they experienced this particular stage in their lives, indicates that high-risk puerperal women seek ties and support.

Conclusions: the challenge of spending an indefinite period of time in a strange environment, away from home, with their babies under the care of health professionals, while apart from their relatives, highlights the need for nursing care during this stage.

Keywords: Postpartum period. Nursing care. Intensive care units, neonatal. Environment.

\section{RESUMO}

Objetivo: compreender as percepções das puérperas de alto risco acerca do ambiente hospitalar sob a luz de Florence Nightingale. 0 puerpério de alto risco é caracterizado pelo período em que a mulher no pós-parto tem seu recém-nascido internado na unidade neonatal e necessita acompanhá-lo, vivendo momentos de transformações.

Métodos: estudo narrativo com abordagem qualitativa, sustentado em Florence Nightingale, realizado em uma instituição pública do sul do Brasil, de janeiro a março de 2010. Sete puérperas acima de 18 anos com recém-nascido internado na unidade neonatal foram sujeitos da pesquisa.

Resultados: as narrativas contextualizadas no hospital, ambiente de cuidado em que vivenciaram essa fase particular de suas vidas, denotam a busca de laços e apoio entre as puérperas de alto risco.

Conclusões: 0 desafio de conviver em ambiente desconhecido por tempo indeterminado, confiando seu filho aos profissionais enquanto está longe dos demais familiares, destaca as necessidades de cuidados de enfermagem nessa fase.

Palavras-chave: Período pós-parto. Cuidados de enfermagem. Unidades de terapia intensiva neonatal. Meio ambiente.

\section{RESUMEN}

Objetivo: comprender las percepciones de las puérperas de alto riesgo sobre el ambiente del hospital a la luz de Florence Nightingale. El puerperio de alto riesgo es cuando la mujer tiene su bebé internado en la unidad neonatal en el posparto, acompañándolo y viviendo momentos de aprensión.

Métodos: estudio narrativo con enfoque cualitativo, basado en Florence Nightingale, realizado en una institución pública del sur de Brasil, de enero a marzo 2010. Siete puérperas mayores de 18 años con los recién nacidos ingresados en la unidad neonatal fueron los sujetos de investigación.

Resultados: las narrativas contextualizadas en el hospital, ambiente del cuidado en el que experimentó esta etapa particular de su vida, destacan como positiva la búsqueda por lazos y apoyo entre esas puérperas.

Conclusiones: el desafío de convivir en un ambiente desconocido por tiempo indeterminado, confiando su hijo a los profesionales mientras están lejos de sus familiares, lo que apunta para las necesidades de cuidados de enfermería en este periodo.

Palabras clave: Periodo posparto. Atención de enfermería. Unidades de cuidado intensivo neonatal. Ambiente. 


\section{DINTRODUCTION}

Postpartum women stay with the newborns during their hospitalization; however, they require specific, postpartum are because she is facing the restorative postpartum period. Because of the risks posed by this period to a woman's life and health conditions, the present study called it High-risk Postpartum period. Since postpartum women experience this period in the hospital, away from their relatives, the nursing team is expected to provide appropriate care to them, to ensure a comfortable environment for their recovery.

According to the Ministry of Health, the high-risk postpartum period concerns "the situations in which a woman's health is affected by pre-existing disorders or intercurrent diseases [...] in the postpartum, generated both by organic factors and unfavorable socioeconomic and demographic factors"(1). The concept of this study proposes a more comprehensive view of high-risk postpartum women, since "women can experience a high-risk postpartum period if their care needs are not appropriately met, even if they have not had high-risk pregnancies ${ }^{\prime \prime 2}$. Therefore, the high-risk postpartum period consists in the period that occurs concomitantly with the admission of the newborn to the neonatal intensive care unit (NICU) and that may influence the mother's vital power during this restorative process inherent to postpartum.

Discharge from hospital is a critical moment for highrisk postpartum women. They experience pain for having to leave their infants in the hospital, and the dream of returning home with their healthy and idealized infants is delayed again ${ }^{(3)}$. The actions of the nursing team, who integrate the hospital healthcare team, regarding the direct care delivered to postpartum women were found to be insufficient ${ }^{(4)}$.

The hospital, particularly the NICU is an environment that favors stress and anxiety. Therefore, humanization of care is required involving mothers, fathers and their families, through effective communication, in order to build confidence ${ }^{(5)}$. Health professionals must be available and assist postpartum women in the recovery process, to make them feel comfortable ${ }^{(6)}$.

Florence Nightingale's theory was used to explore the theoretical framework that defined metaparadigms of nursing, including environment. The internal environment of the individual is related to psychological aspects, which can be affected by the elements of the external environment, such as lighting, heating, noise, smell, among others. Neglect of the elements of the ex- ternal environment by the nursing staff affects the internal environment of the patients, which is directly related to the worsening of their health condition, affecting their vital power ${ }^{(7)}$.

High-risk postpartum women may feel uncomfortable in the hospital setting, and the nursing staff is supposed to turn the hospital setting into a more welcoming environment, to help these women regain their vital power. However, when they are merely regarded as the persons who accompany their newborn babies, their care needs are neglected, with a negative impact on their restorative process and vital power.

Thus, it is important to implement actions that positively affect the internal environment of these high-risk postpartum women, from the mobilization of the external environment ${ }^{(7)}$. The care provided by the nursing and the multidisciplinary teams to assist high-risk postpartum women in their recovery process include providing a welcoming environment in the hospital where these women may rest while they take care of their hospitalized newborn babies.

In the analysis of the relationship between hospital setting and high-risk postpartum period, which influences the recovery process of postpartum women, we stress the importance of interaction between the nursing staff and these women for the creation of an environment of care to assist in this sensitive moment of admission to the NICU. These reflections provided a stimulus to the development of this study based on the following guiding question: How do high-risk postpartum women perceive the hospital setting during the hospitalization of their newborn babies? This study aims to shed light on how high-risk postpartum women perceive the hospital setting according to Florence Nightingale's theory.

\section{Q METHOD}

Qualitative study with narrative approach ${ }^{(8)}$ conducted in a public institution in which assistance is entirely provided under Brazil's Unified Health care System (SUS), in the Southern region of Brazil, from January to March 2010, based on a doctoral thesis in nursing(9).

The setting of this study is a 4-bed recovery and postpartum room for mothers, with a private bathroom, to accommodate the mothers of newborns in the Neonatal intensive care unit (NICU). This area is located in the maternity of the hospital, adjacent to the Neonatal Unit and other wards of the Maternal and Child Service.

The subjects of the study were seven postpartum women who met the following inclusion criteria: mothers 
aged above 18 years of infants admitted to the NICU. The exclusion criteria were be less than 18 years and mother of infant not admitted to the NICU. Data was collected by narrative interviews, and these were recorded and transcribed. The guiding questions were: "Tell me your story from childbirth to the present time and how did you feel during labor and after you gave birth; How do you perceive nursing care delivered to you?" Data collection occurred in a private room close to the NICU and was concluded with the identification of the words repeated in the narratives ${ }^{(8)}$.

The method used in data collection was narrative interview, which allows telling stories. The following steps were observed: "Preparation; Initiation; Central Narrative; Questioning and Conclusive Speech"(8).

Data treatment and analysis was based on the narrative interview proposed by Fritz Schütze, which involves six phases of data systematization ${ }^{(8)}$, as follows: first phase: Detailed transcription of the verbal material; second phase: Text divided into indexed material (has specific reference to "who did what, where and why") and non-indexed material (express values, judgments and all forms of life wisdom); third phase: Use of indexed components of the text to analyze the order of the events for each individual, that is, the timelines; fourth phase: The non-indexed text dimensions are investigated as "knowledge analysis"; fifth phase: Grouping and comparison of individual timelines and sixth phase: Contextualized comparison of cases with the identification of individual timelines. Similarities are established for determining collective timelines ${ }^{(8,10)}$.

Regarding ethical aspects, formal consent of the participating institution and approval of the Research Ethics Committee of Universidade Federal de Santa Catarina (UFSC), under no 1132/2010 were obtained prior to the beginning of the study. All participants were informed about the purpose of the research and signed the Informed Consent Form. For preservation of the identity of the subjects, the letter $\mathrm{P}$, for postpartum, followed by numbers one to seven were used.

\section{RESULTS AND DISCUSSION}

Analysis of this manuscript was based on analysis of the individual and collective timelines.

The subjects of this study faced the impact of admission to the NICU, but attempted to overcome it, in spite of the difficulties reported. Dealing with the premature birth of a child has affected high-risk postpartum women, generating concern with the future. For P3, noticing the expression of pain of her newborn in the neonatal ICU aroused negative feelings:

On the second day I saw her expression of pain, I could see that she was in pain and I was very sad that day, and she would not stop, she was agitated and moving all the time [...] I was afraid that she would not survive [...]. (P3)

High-risk postpartum women need guidance on the $\mathrm{NICU}$, the therapies used and newborn reactions, to become familiar with the hospital setting and reduce their anxiety levels.

When they are separated from their newborn babies, the parents feel uncomfortable, especially the mother who was very attached to the baby throughout the entire pregnancy ${ }^{(11)}$. Understandably, one of the most stressful aspects in admission of infants to the NICU is related to the feeling of helplessness in face of the pain experienced by the newborn ${ }^{(12-13)}$. These traumatic experiences may interfere negatively on mother-infant relationships and on the capacity of mothers to bond with their children ${ }^{(14)}$.

We deem it important to stress Nightingale's concern with the emotional fatigue related to stressful aspects of disease and hospitalization, which may have a negative impact on vital power ${ }^{(7)}$.

Caring for her newborn admitted to the NICU and spending a very long time away from home and her families generated conflicting feelings in the respondents:

\section{[...] it is very difficult and stressful, and all I want to do is pick up my baby and go home. (P2)}

Then the nurse said, "You can go to the recovery and postpartum room. If there is no vacancy, we can seek the kangaroo mother care setting or any other place available". This made me feel comfortable. God knows I would never leave my child alone. If necessary, I would stay outside the hospital, sleep sitting in a chair... It is comforting to know that I can stay all the time close to my child. This reassures me. (P1)

High-risk postpartum women are separated from the other family members to stay with their infants in the recovery and postpartum room during the time they are admitted to the NICU and, thus, they experience ambiguous feelings: Although they decide to stay in the recovery and postpartum room, they also long to return to their homes to resume their daily routines ${ }^{(15)}$. Accord- 
ing to Florence Nightingale, humans have a vital power that can be influenced by aspects such as ventilation, noise, lighting, cleaning and aeration. However, according to the author, high quality care involves more than an appropriate physical environment.; it also involves meeting the psychosocial needs of the patients to ensure the best possible conditions for treating them.: ${ }^{7: 146)}$. Therefore, the care delivered to postpartum women involves providing an appropriate place for them during the time their infants are admitted to the NICU, helping them deal with the exhaustion caused by the status of their infants and separation from their families, among other aspects.

In their narratives, these high-risk postpartum women demonstrated that the care delivered by the nursing team was very beneficial to them and strengthened their Vital Power:

God, this brings me peace of mind and makes me feel happy; I know that if I have to leave this place for a few hours my baby will be well cared. It comforts me to know that he is all right.. (P1)

They are nice people, very considerate, who take good care of the babies [...] they are very attentive, take good care of the children, both in terms of cleanliness and feeding. (P2)

When high-risk postpartum women realize their infants are being well taken care of, they build a relationship of confidence with the nursing team and are also indirectly taken care of. Nightingale affirmed that "(...) there is universal experience as to the great importance of high quality nursing care for determining the consequences of the disease $\mathrm{e}^{\prime \prime(7: 15)}$

The admission of a child to a Newborn Intensive Care Unit is a sensitive and challenging experience for mothers, and the relationships established with the nursing team have an impact mother-infant interaction in the $\mathrm{NICU}^{(16)}$. When the mothers have confidence in the nursing staff, they are satisfied with the care delivered to their infants ${ }^{(17)}$.

The support of the multidisciplinary team throughout the stressful situations experienced during hospital admission, labor and the postpartum period was stressed in the statements of the participants:

The psychologist gave us a strong support. She talked a lot to us, and so did the interns, who were also in the room. On the day of my cesarean section I was very nervous, crying, and, then the psychologist talked to me and explained in detail the cesarean procedure... so far I had not gone through this experience, only child birth and was very afraid of it because of my blood pressure. (P4)

I was taking care of my baby in the NIC and the psychologist, or social worker, bought my blood pressure medication. She was very considerate and kind too. (P7)

Women who experience a high-risk postpartum period are on a boundary between health and disease, because they are not sick. They are recovering from the transformations occurred throughout pregnancy and postpartum and are also concerned with their infants admitted to the $\mathrm{NICU}$, and this process involves nursing care.

Multidisciplinary support to the family members is very important during neonatal interaction ${ }^{(18)}$. Humanized care during labor, delivery and the postpartum period for these women involves a "holistic approach, welcoming, bonds and communication" (19:125).

Nightingale affirmed that: "the recovery process established by nature, which is called disease, has been retarded due to lack of knowledge or attention to one or all of these factors; as a consequence, pain and suffering occur, or else the entire process is interrupted $^{\prime \prime(7: 14)}$. Knowledge about the process and the factors involved such as fresh air, light, warmth, cleanliness and care in diet should be shared with the health team, so that all the professionals have access to the means that strengthen human vital power.

Living with other mothers who are experiencing the same situation, high-risk postpartum period, is positively assesse in the statements:

[...] I made friends with the girls who were sharing the same room (4-bed recovery and postpartum room for mothers). We were always talking, supporting each other, which helped us go through all of this in a more pleasant way. (P4)

It was very nice, I made friends with people there. It was very nice. (P6)

In the recovery and postpartum room, the mothers shared their experiences, their difficulties, since they faced the same situation, that is, admission of their newborn babies to the NICU during the neonatal period. Therefore, they created a network of solidarity and friendship motivated by their common needs and experiences.(15).

Nightingale stressed that patients often prefer to talk with other patients, as these can understand their thoughts 
without judging them(7). High-risk postpartum women identify with other women in the same situation and are mutually supportive during neonatal hospitalization.

The narratives of the respondents indicate that being away from their homes and families, these women experienced a restorative process after delivery, which, combined with the stress of the admission of their newborns to the $\mathrm{NICU}$, led to exhaustion. The support and care of the nursing staff and the multidisciplinary team and the support of other women experiencing similar situations helped them recover from this stressful period.

High-risk postpartum women spend most of their time at the hospital caring for their newborn babies. They experience the postpartum period in the following settings: rooming-in setting, recovery and postpartum room, neonatal unit and the facilities of the Kangaroo mother care method. The recovery and postpartum room was created to facilitate and stimulate mother-infant interaction, even when the infant is receiving intensive care, providing rest and appropriate nutrition to the mother ${ }^{15}$. As dependências do método Mãe Canguru é um local em que se pratica uma estratégia de cuidado neonatal, a qual implica contato pele a pele precoce entre mãe e bebê ${ }^{(4)}$.

The respondents shared their narratives that expressed their feelings towards this period of their lives, including their relationships with the nursing staff, with other postpartum women, the condition of their babies and how they dealt with hospital admission and separation from the family; these narratives were contextualized (they concerned the hospital setting, care environment where they experienced this particular stage of their lives).

The way of perceiving the hospital admission and evolution of their infants influences the concept of environment for each woman. For P6, each improvement in the condition of her newborn is a step toward discharge, represented by the transition between hospital accommodations:

Leaving the hospital room was a step forward, and then I was taken to the recovery and postpartum room with my baby, and finally to the Kangaroo mother care setting, that is, another step forward. (P6)

For P5, the hospital environment is compared to confinement because of the long period of hospitalization in pregnancy, followed by the recovery and postpartum room for mothers to stay while they accompany their infants at the NICU, and, finally, to the Kangaroo mother care setting:
I feel depressed for having to stay so many days in the recovery and postpartum room without going out. It's difficult when you are confined [...] but thank God, it's almost over. (P5)

For P7, in turn, the hospital environment is similar to her home; for $\mathrm{P} 2$, it is hard to stay away from home:

[...] it was like being at home [in the recovery and postpartum room], and safer. (P7)

It was very unpleasamt: we plan so many things, having the baby and then going home.. it's very stressful; we are torn between the need to stay here and an urge to go home... and we don't feel comfortable here because we are not at home...it's very difficult. (P2)

For P3, she received valuable guidance on breastfeeding:

I stayed four days in the recovery and postpartum room with my infant... it was easier there. I pumped my milk... it was difficult in the beginning. I was told to drink a lot of water and juice and my breasts became harder and swollen, which was very painful and made it difficult for me to continue breastfeeding, but [the nursing technician] was very considerate and handy and on the second day I learned to pump the milk and I am storing it at the lactation center. (P3)

The hospital setting (recovery and postpartum room) is identified in the narratives of P1 and P7 as a place that provides the necessary dietary and physical structures:

[...] It's great there... I have fridge, air conditioning (yesterday it was very hot and the air conditioning was on... I can bring fruits and store them in the refrigerator... breakfast is served, and towels are provided for bathing... I have everything. Why ask for more? Should I ask for a SPA? No, it's perfect for me. (P1)

It's very good. I am very well treated. Breakfast, lunch and an afternoon snack are served.. It's very good. (P7)

Each respondent experienced the admission to hospital of each newborn bay in the neonatal intensive care unit (NICU) during the high-risk postpartum period in a particular way. However, analysis of the narratives and comparison of the cases within the hospital setting showed that these women shared feelings and perceptions, as follows: fear for their health and that of the child, 
they missed their families and homes. They were happy to be close to their babies at all times and to count on the hospital structure.

We stress the importance of an appropriate external environment with ventilation and heating, sanitation, lighting and cleaning, and concern with psychological aspects (the internal environment) ${ }^{(7)}$. Developing an organizational culture in the hospital environment that supports the relationship between the mother, her family and the hospitalized newborn, involving the health care team is essential to meet the physical and emotional needs of these human beings ${ }^{(20)}$.

The experience of a high-risk postpartum period affects the lives of women and generate conflicting feelings. The hospital setting is perceived as the place where they will get better, but they are uncertain of their discharge from hospital; the evolution of the rooming-in setting to the recovery and postpartum room and, finally, to the Kangaroo mother care setting is seen as something positive, but also as confinement that deprives them from contact with the other family members and their previous routine.

\section{口FINAL CONSIDERATIONS}

In the present study the hospital environment that houses high-risk postpartum women, was found to be an environment that does not provide specific care to these women. There is an urgent need to understand the restorative process experience and its influence on the vital power of these women, so that the nursing care provided in the high-risk postpartum period may interfere in this environment in a positive way.

A major limitation of this study was that it was conducted at only one hospital. Also, the interviews were conducted in the hospital setting, and this could inhibit respondents from freely expressing their views, fearing that these influence the care provided to their infants and to themselves.

Based on Florence Nightingale's theory, we understand that high-risk postpartum women, as complex and unique human beings who have a vital power, experience a restorative process. Therefore, nursing should focus on the peculiarities of high-risk postpartum women and deliver appropriate and effective care to strengthen their vital power. By assuming that both the external and the internal (psychological) environments influence the composition of a caring environment for these women, nursing will provide holistic care that comprises all aspects involved in the high-risk postpartum period.

\section{REFERENCES}

1. Ministério da Saúde (BR). Portaria 1020 de 29 de maio de 2013. Institui as diretrizes para a organização da Atenção à Saúde na Gestação de Alto Risco e define os critérios para a implantação e habilitação dos serviços de referência à Atenção à Saúde na Gestação de Alto Risco, incluída a Casa de Gestante, Bebê e Puérpera (CGBP), em conformidade com a Rede Cegonha. Diário Oficial da União [da] República Federativa do Brasil. 2013 maio 31;150(103 Seção 1):72-5.

2. Kunzler IM. 0 cuidado às mulheres no puerpério de alto-risco: aplicando o modelo de cuidado de Carraro fundamentado em Florence Nightingale [dissertação]. Florianópolis (SC): Universidade Federal de Santa Catarina; 2006.

3. Oliveira K, Veronez M, Higarashi IH, Corrêa DAM. Vivências de familiares no processo de nascimento e internação de seus filhos em UTI neonatal. Esc Anna Nery. 2013;17(1):46-53.

4. Corrêa ACP, Arruda TM, Mandú ENT, Teixeira RC, Arantes RB. Humanização da assistência à puérpera: concepções de profissionais de enfermagem de um hospital público. Cienc Cuid Saúde. 2011;9(4):728-35.

5. Salimena AMM, de Paiva Oliveira C, Buzatti JR, Moreira AMF, Amorim, TV. A comunicação entre enfermeiros e pais de recém-nascidos em unidade de terapia intensiva neonatal. HU Rev. 2013;38(1):79-83.

6. Rocha SS, Olivindo DDF, Sá CN, Fonseca LF. Percepção da enfermagem em relação às mães no cuidado de recém-nascidos na unidade de terapia intensiva neonatal. Enferm Foc0. 2013;4(1):45-8.

7. Nightingale F. Notas sobre enfermagem: 0 que é e 0 que não é. São Paulo: Cortez; 1989.

8. Jovchelovitch S, Bauer MW. Entrevista narrativa. In: Bauer MW, Gaskell G, organizadores. Pesquisa qualitativa com texto e imagem: um manual prático. 9a ed. Petrópolis: Vozes; 2011. p. 90-113.

9. Frello AT. Puerpério de alto risco e cuidado de enfermagem: influência no poder vital das mulheres [tese]. Florianópolis (SC): Universidade Federal de Santa Catarina; 2013.

10. Schütze F. Die Technik des narrativen interviews in interaktionsfeldstudien: dargestellt an einem projekt zur erforschung von kommunalen machtstrukturen. Bielefeld: Universität Bielefeld, Facultät für Sociologie; 1977. [manuscrito]

11. Sá RC, Costa LMFP, Sá FE. Vivência materna com filhos prematuros em uma unidade de tratamento intensivo neonatal. Rev Bras Promoç Saúde. 2012;25(2):2583-9.

12. Woodward LJ, Bora S, Clark CAC, Montgomery-Hönger A, Pritchard VE, Spencer $C$, et al. Very preterm birth: maternal experiences of the neonatal intensive care environment. J Perinatol. 2014;34(7):555-61.

13. Lasiuk GC, Comeau T, Newburn-Cook C. Unexpected: an interpretive description of parental traumas' associated with preterm birth. BMC Pregnancy Childbirth. 2013; 13(Suppl 1):S13.

14. Coppola G, Cassibba R. Mothers'social behaviours in the NICU during newborns' hospitalisation: an observational approach. J Reprod Infant Psychol. 2010 May;28(2):200-11.

15. Dittz ES, Mota JAC, Sena RR. 0 cotidiano no alojamento materno, das mães de crianças internadas em uma unidade de terapia intensiva neonatal. Rev Bras Saúde Matern Infant. 2008 jan./mar.;8(1):75-81.

16. Frello AT, Carraro TE. Enfermagem e a relação com as mães de neonatos em unidade de terapia intensiva neonatal. Rev Bras Enferm. 2012;65(3):51421. 
17. Schmidt K, Mello F, Rosseto E, Souza S. Avaliação da assistência de enfermagem em unidade neonatal na perspectiva dos pais. Cogitare Enferm. 2010;15(3):446-60.

18. Lopes FN, Fialho FA, Dias IMAV, Almeida MB. A vivência do enfermeiro diante da privação materna em unidade de terapia intensiva neonatal. HU Rev. 2011;37(1):39-46.
19. Reis LS, Silva EF, Waterkemper R, Lorenzini E, Cecchetto FH. Percepção da equipe de enfermagem sobre humanização em unidade de tratamento intensivo neonatal e pediátrica. Rev Gaúcha Enferm. 2013;34(2):118-24.

20. Flacking $R$, Lehtonen $L$, Thomson G, Axelin A, Ahlqvist S, Moran VH, et al. Closeness and separation in neonatal intensive care. Acta Pædiatrica. 2012;101(10):1032-7.

\section{Author's address:}

Ariane Thaise Frello Roque

Rua Osvaldo Aranha, 82/802, Centro

88802-130 Criciúma - SC

E-mail: arianethaise@yahoo.com.br
Received: 17.10.2014

Approved: 30.09 .2015 